Title of article: „Ocena technologiczności konstrukcji w procesach montażu według zmodyfikowanej metody Lucas DFA” (“Evaluation of design manufacturability in assembly processes by modif ied Lucas Design for Assembly method")

Mechanik, Vol. 91, No. 7 (2018): pages 532-534

DOI: https://doi.org/10.17814/mechanik.2018.7.75

\title{
Evaluation of design manufacturability in assembly processes by modified Lucas Design for Assembly method
}

\author{
Ocena technologiczności konstrukcji w procesach montażu według \\ zmodyfikowanej metody Lucas DFA
}

\section{JÓZEF MATUSZEK TOMASZ SENETA ALEKSANDER MOCZAŁA *}

The paper presents a methodology for the design of the production product from the point of view of manufacturability design criterion. The evaluation method from the point of view of machining, assembly and organization of production was discussed on the example of a modified method of assessing the technological character of the structure from the point of view of the assembly operation (Design for Assembly - DFA).

KEYWORDS: production process design, construction manufacturability

The development of machining technology (thanks to the automation and extension of the possibility of making objects of complex construction) in connection with a significant share of manual work in the assembly processes of finished products has led to a change in the approach to the production of new products [5]. The design process of the new product is shown in Figure 1.

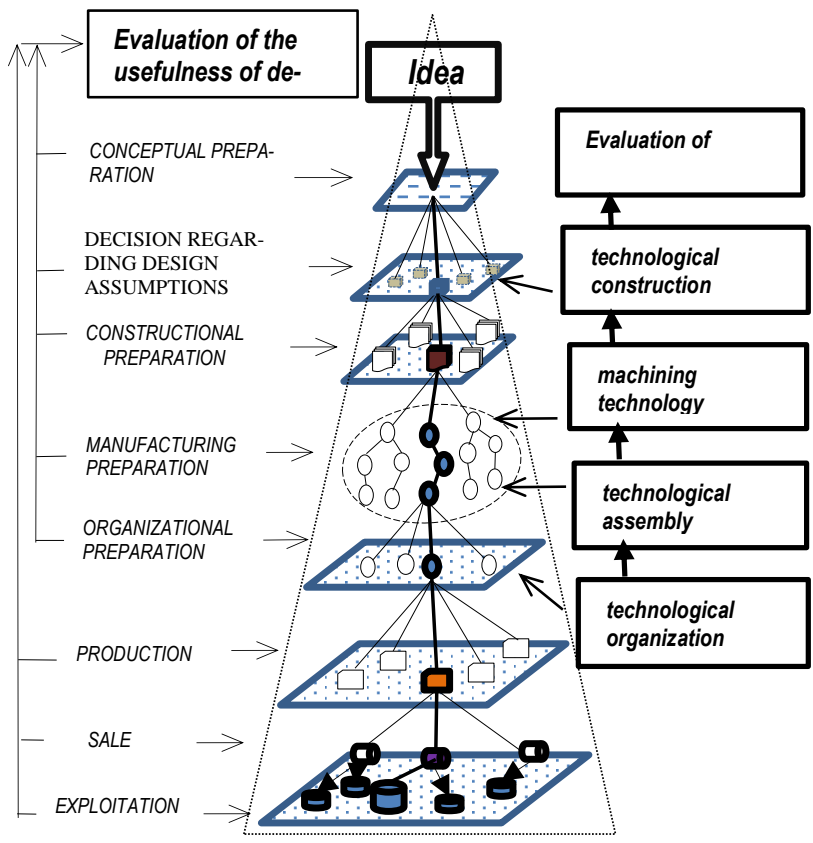

Fig. 1. The course of designing the production process of a new product

* prof. dr hab. inż. Józef Matuszek, jmatuszek@ath.bielsko.pl, mgr inż. Tomasz Seneta, tomasz.seneta@zf.com, dr inż. Aleksander Moczała, amoczala@ath.bielsko.pl, Akademia Techniczno-Humanistyczna w Bielsku-Białej, Wydział Budowy Maszyn i Informatyki, Katedra Inżynierii Produkcji
The design process should be determined from the point of view of different usability criteria. The assessment is based on: marketing and conceptual preparation; documentation construction, production and organization; implementation of the production process; distribution; conditions for the operation and decommissioning of the product.

Errors of the designed process generate large costs associated with eliminating defects at the production stage. In publications concerning large-scale production (e.g. in the automotive industry), much attention is paid to the issues of the construction's technical character from the point of view of assembly.

Methods of forming assembly processes, referred to by the abbreviations DFA (design for assembly) or PdM (design for assembly), are presented in the works [2-6, 8]. The most common method of DFA is the Lucas DFA method [6].

\section{Modified Lucas DFA method}

The traditional Lucas DFA technology benchmark is based on the determination of three indicators whose values are related to the relative measure of installation difficulty. As a result of the assessment, the aim is to reduce the number of assembled elements of the final product (functional analysis) and analyze the assembly operation in terms of difficulty, complexity and assembly time (maneuvering analysis and assembly method).

The project effectiveness indicator based on functional analysis is defined by the formula:

$$
W_{\mathrm{ep}}=\frac{L_{\mathrm{kA}}}{\left(L_{\mathrm{kA}}+L_{\mathrm{kB}}\right)} \times 100 \%
$$

where: $W_{\mathrm{ep}}$ - project effectiveness indicator; $L_{\mathrm{kA}}$ - number of $A$ components (fulfilling the function of the product); $L_{\mathrm{kB}}$ number of $B$ components (characterized by a lack of performance of the product function, e.g. rivets, washers)

Assessment of maneuvering of assembled components of the product determines the maneuvering coefficient of $W_{\text {man }}$ :

$$
\begin{aligned}
& W_{\text {man }}=I_{\text {man }} / L_{k A} \\
& I_{\text {man }}=L_{p A}+L_{p B}+L_{p C}+L_{p D}
\end{aligned}
$$

where: Iman - maneuvering index; $L_{p A}, L_{p B}, L_{p C}, L_{p D}$ - sum of points from segments $A, B, C, D$ according to [6].

The assessment of the course of assembly operations from the point of view of feasibility is defined by the formula describing the results of the analysis of the $W_{\text {mon }}$ coefficient of assembly: 


$$
W_{\text {mon }}=\frac{W_{\mathrm{m}}+W_{\mathrm{d}}}{L_{\mathrm{kA}}}
$$

where: $W_{\mathrm{m}}$ - main activity indicator $\left(W_{\mathrm{m}}=L_{\mathrm{mA}}+L_{\mathrm{mB}}+L_{\mathrm{mC}}+\right.$ $L_{\mathrm{mD}}+L_{\mathrm{mE}}+L_{\mathrm{mF}}$, where $L_{\mathrm{mA}}, \ldots, L_{\mathrm{mF}}$ - sum of segments $A, \ldots$, $F$ according to [6]); Wd - additional actions indicator.

The analysis allows to make structural changes to the product, improving the efficiency of assembly processes [6]. The presented course of proceedings was developed for large-scale production. The study attempts to modify this method so that it can also be used in the case of mass production and small lot production. The Lucas DFA method - due to its simplicity in comparison with other methods - may be susceptible to such modification.

According to fig. 1, the technical character of the structure can be considered in terms of machining and the organization of machining and assembly processes. From the point of view of the production organization, it is important to unify and normalize the components of the product, defined by the unification indicator:

$$
W_{\mathrm{unk}}=\frac{L_{\mathrm{kU}}}{\left(L_{\mathrm{kU}}+L_{\mathrm{kNU}}\right)} \times 100 \%
$$

where: $L_{\mathrm{kU}}$ - the number of unified and standardized components; $L_{\mathrm{kNU}}$ - number of non-unified and non-standard components.

The use of group machining plans, group operations and operations not requiring retooling of workplaces is associated with a reduction in the costs of preparing manufacturing processes. The process efficiency improvement can be determined by the Unification Indicator of Wuno Operations:

$$
W_{\mathrm{uno}}=\frac{L_{\mathrm{OG}}}{\left(L_{\mathrm{OG}}+L_{\mathrm{ONG}}\right)} \times 100 \%
$$

where: LOG - the number of operations carried out that do not require changing of work positions; LONG - the number of operations requiring retooling of workplaces.

\section{Example}

The calculation in the example shows that the structure is non-technological. In the applied method, $W_{\mathrm{ep}}=23 \%$ (authors of publication [9] give $60 \%$ as a minimum), $W_{\text {man }}$ $=2.80$ and $W_{\text {mon }}=11.84$ (according to [9] both indicators should be less than 2.5 ).

On the basis of the obtained values of ratios and coefficients, the structure of the designed transmission was changed (fig. 2). The transmission belongs to a series of types, consisting of several gears of various sizes, in which the same solutions of the construction form were applied.

$$
\begin{aligned}
& L_{\mathrm{kA}}=24, L_{\mathrm{kB}}=81, L_{\mathrm{kA}}+L_{\mathrm{kB}}=105 \\
& W_{\mathrm{ep}}=24 / 105=0,23(23 \%) \\
& I_{\mathrm{man}}=L_{\mathrm{mA}}+L_{\mathrm{mB}}+L_{\mathrm{mC}}+L_{\mathrm{mD}}=48+10,9+2,7+5,6= \\
& 67,2 \\
& L_{\mathrm{kA}}=24 \\
& W_{\mathrm{man}}=67,2 / 24=2,80 \\
& L_{\mathrm{kA}}=24 \\
& W_{\mathrm{m}}=L_{\mathrm{pA}}+L_{\mathrm{pB}}+L_{\mathrm{pC}}+L_{\mathrm{pD}}+L_{\mathrm{pE}}+L_{\mathrm{pF}}=108,2+2,1+ \\
& 10,5+18+11,9+7+126,5=284,2 \\
& L_{\mathrm{kA}}=24 \\
& W_{\mathrm{m}}=284,2
\end{aligned}
$$

\section{$W_{\text {mon }}=284,2 / 24=11,84$}

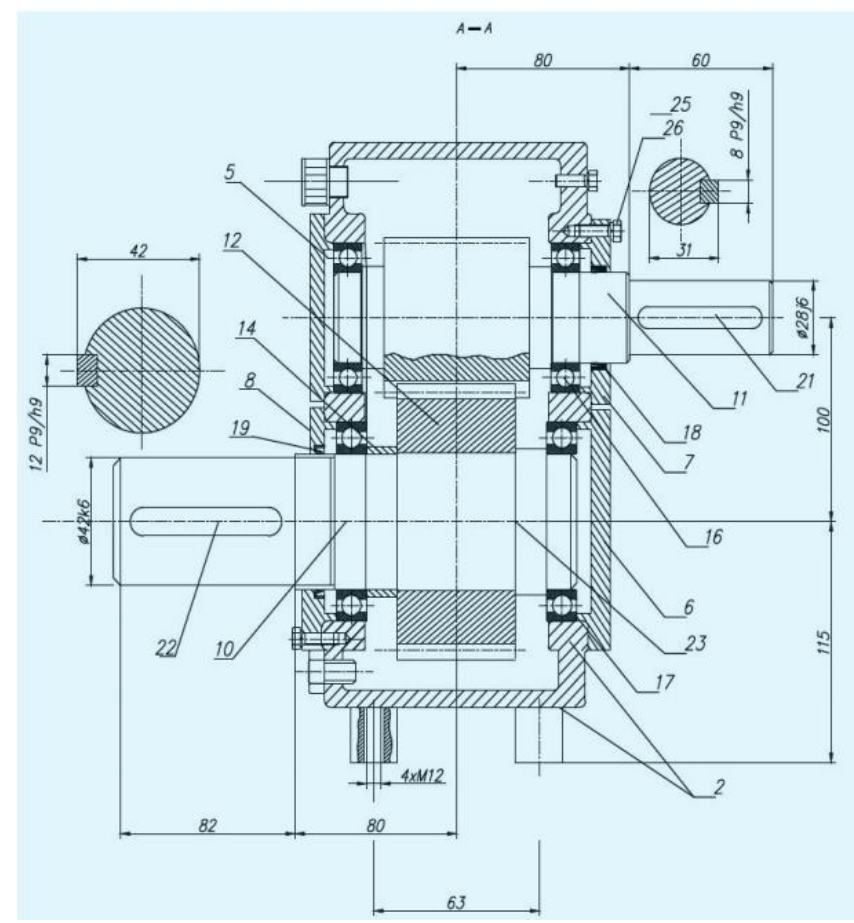

Fig. 2. Diagram of the analyzed transmission: 2 - body; 5, 6, 7, 8 bearing pads; 10 - roller; 11 - pinion; 12 - gear wheel; 14 - spacer rings; 17,16 - bearings; 18,19 - seals; $21,22,23$ - grooves; 25,26 washers, screws

The results of technological analysis of the new construction version of the transmission are presented in tabular form (fig. 3). The operations with assigned parameters resulting from functional analysis (in the form of components included in group $A$ or $B$ [6]), maneuvers (within segments $A, B, C$ and $D[6]$ ) and assembly (according to indicators main activities $A, B, C, D, E$ and $F$ and additional operations according to the procedure given in [6]). The following indicators were again determined: $W_{\text {ep }}$ efficiency of the project, $W_{\text {man }}$ maneuvers and $W_{\text {mon }}$ mountability.

Based on the data presented in the table (fig. 3) $L_{k a}=18$, and $L_{\mathrm{kB}}=9$. After substituting for formula (1), it is obtained:

$$
W_{\text {ep }}=\frac{18}{18+9} \times 100 \%=67 \%
$$

In addition, $L_{p A}=27, L_{p B}=4.3, L_{p C}=1.4$ and $L_{p D}=3$, thus: $I_{\text {man }}=L_{p A}+L_{p B}+L_{p C}+L_{p D}=7+4.3+1.4+3=35.2$. After substituting these values for formula (2):

$$
W_{\text {man }}=\frac{35,2}{18}=1,96
$$

Summing up values of $L_{\mathrm{mA}}=54, L_{\mathrm{mB}}=1.4, L_{\mathrm{mC}}=0, L_{\mathrm{mD}}=$ $7.5, L_{\mathrm{mE}}=9.1, L_{\mathrm{mF}}=6.3$ and $S_{\mathrm{ec}}=35$, the main activity coefficient $W_{\mathrm{m}}=112.8$ was calculated.

On the basis of formula (3), the coefficient of mountability was calculated:

$$
W_{\text {mon }}=\frac{112,8}{18}=6,27
$$




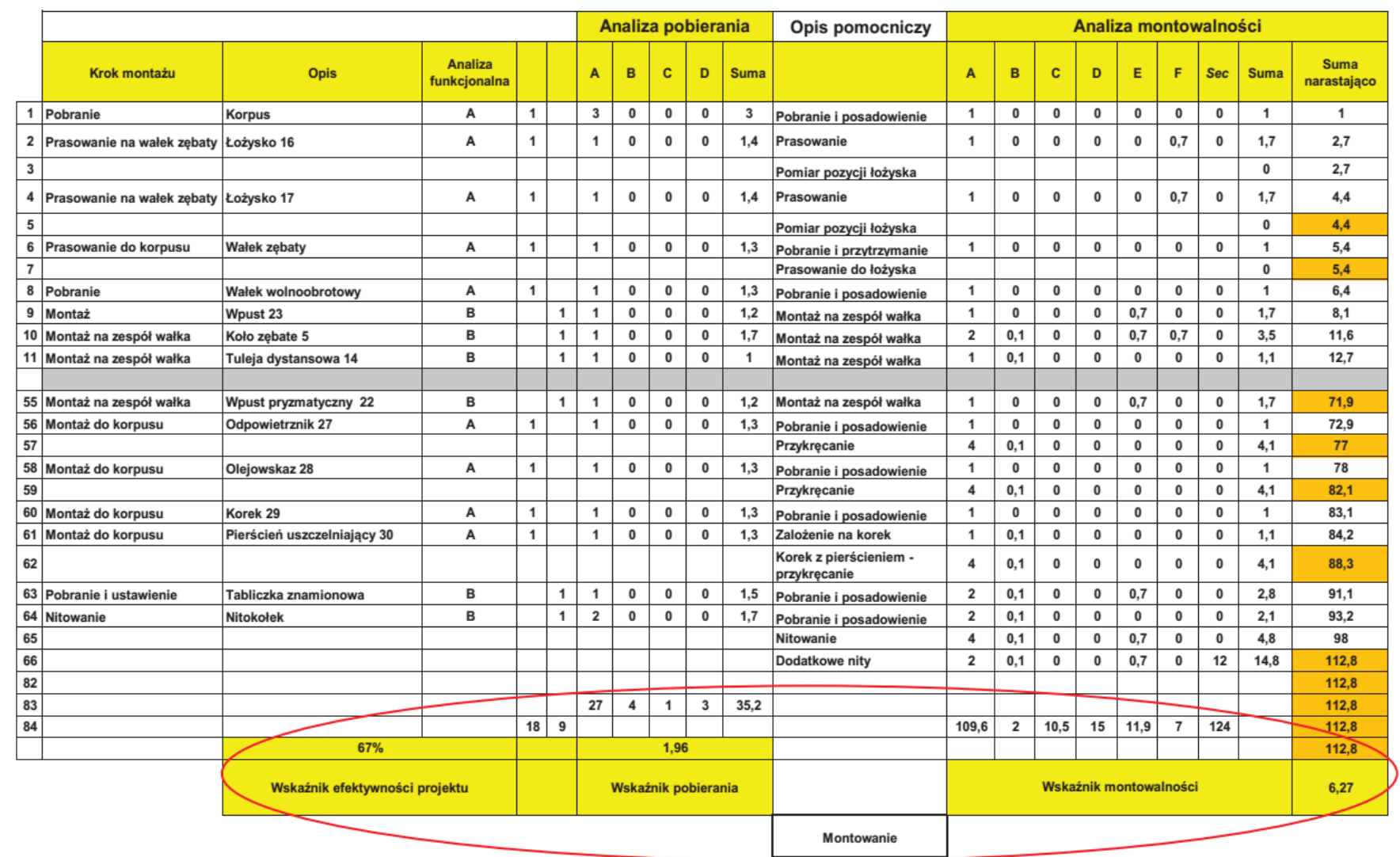

Fig. 3. Results of the technological analysis of gear assembly (fig. 2) after the technological assessment

According to the calculations presented, it can be concluded that the results of the analysis for cast iron cast gearboxes are better compared to the results for welded gears. The $W_{\text {ep }}$ project efficiency ratio should have the highest possible value - the change was $67 \%$. Maneuvering coefficients and the mountability of $W_{\text {man }}$ and $W_{\text {mon }}$ should be as small as possible - after the change they are 1.96 and 6.27 respectively.

Component unification indicator for gear units from fig. 2 (only the body and cover are not unified - they are not included in other products) is:

$$
W_{\text {unk }}=\frac{25}{(25+2)} \times 100 \%=93 \%
$$

The treatment unification index is:

$$
W_{\text {uno }}=\frac{58}{(58+67)} \times 100 \%=46 \%
$$

\section{Conclusions}

Analyzing the values of the evaluation parameters of the gear assembly, it can be concluded that:

- assessment of parameter values (fig. 3) may be the basis for analyzing the technological character of the product structure;

- the assessment should take into account many other factors related to sales, servicing, availability of spare parts, production line, available assembly techniques, the level of automation, cooperative services, the possibility of using commercial components, the technical culture of the crew, etc.;

- the method can be successfully used also for smaller batches of manufactured products - in the case of production of a group of technologically similar products, e.g. generalpurpose toothed gears;
- it is helpful when assessing the structure to standardize machining and assembly operations - it makes it easier to estimate the times of performing these operations;

- presented procedure can be useful for: designers, people implementing new products for production and production engineers, carrying out rationalization work at the stage of improving and expanding the production range.

\section{REFERENCES}

1. Abdullah A., Popplewell K., Page C.J. "A review of the support to tools for the process of assembly method selection and assembly planning". International Journal of Production Research. 41, 11 (2003): pp. 2391-2410, 2396.

2. Egan M. "Design for Assembly in the Product Development Process-A Design Theory Perspective". Thesis for the degree of Licenciate of Engineering. Chalmers. Report No. 1997-11-14, 1997.

3. Favi C., Germani M., Mandolini M. "Design for manufacturing and assembly vs. design to cost: toward a multi-objective approach for decision-making strategies during conceptual design of complex products". Procedia CIRP. 50 (2016): pp. 275-280.

4. Kuo B.T.C., Huang S.H. Zhang H.C. "Design for manufacture and design for ' $X$ ': concepts, applications, and perspectives". Computers \& Industrial Engineering. 41, 3 (2001): pp. 241-260.

5. Matuszek J., Seneta T. „Algorytmizacja procesu wdrażania nowegp produktu w warunkach wielkoseryjnej produkcji". Mechanik. 7 (2016): pp. 755-757.

6. Matuszek J., Seneta T. "Evaluation of design manufacturability in new product production launches by Lucas DFA method". Mechanik. 7 (2017): pp. 523-525.

7. Pasichnyk V., Lashyna Y. „Montażowo zorientowane projektowanie z zastosowaniem DFA Expert”. Zeszyty Naukowe Politechniki Rzeszowskiej: Mechanika. 279 (2011): pp. 9-16.

8. Praca zbiorowa. Advanced Product Quality Planning (APQP) and Control Plan. Reference Manual. AAIG - Chrysler Corporation, Ford Corporation, General Motors Corporation. Adare Carvin., Unit 1, Trade Link, Western Ave, West Thurrock, Grays, Essex England. 9. Swift K., Brown N. Design for Assembly/Manufacturing Analysis Practitioners Manual (version 10.5). University of Hull, 1994. 
10. Więcek D. „Określanie kosztów produkcji według rachunku kosztów działań”. Zeszyty Naukowe Politechniki Śląskiej:

Organizacja i Zarządzanie. 42 (2007): pp. 117-124

Translation of scientific articles, their computer composition and publishing them on the website www.mechanik.media.p by original articles in Polish is a task financed from the funds of the Ministry of Science and Higher Education designated for dissemination of science.

\section{Ministry of Science and Higher Education \\ Republic of Poland}

